\title{
Lack of Association of LRP5 and LRP6 Polymorphisms with Type 2 Diabetes Mellitus in the Japanese Population
}

\author{
MASAKO ZENIBAYASHI, KAZUAKI MIYAKE, YUKIO HORIKAWA*, YUSHI HIROTA, TETSUYA TERANISHI, \\ KUNICHI KOUYAMA, KAZUHIKO SAKAGUCHI, JUN TAKEDA* AND MASATO KASUGA \\ Division of Diabetes, Metabolism, and Endocrinology, Department of Internal Medicine, Kobe University Graduate School of \\ Medicine, Kobe 650-0017, Japan \\ *Department of Diabetes and Endocrinology, Division of Molecule and Structure, Gifu University School of Medicine, Gifu 501-1194, \\ Japan
}

\begin{abstract}
Aims. A missense mutation in the low density lipoprotein receptor-related protein 6 gene (LRP6) was recently shown to be responsible for a disorder characterized by early-onset coronary artery disease as well as diabetes mellitus (DM), hyperlipidemia, hypertension, and osteoporosis. Mice deficient in LRP5, a closely related paralog of LRP6, manifest a marked impairment in glucose tolerance. The aim of the present study was to examine whether common variants of LRP5 and LRP6 are associated with Type 2 DM or dyslipidemia in Japanese individuals. Methods. Thirteen single nucleotide polymorphisms (SNPs) of LRP6 and nine SNPs of LRP5 were genotyped in a total of 608 Type 2 DM patients and 366 nondiabetic control subjects (initial study). An association analysis was then performed for each SNP and for haplotypes. For some of the SNPs, we provided another sample panel of 576 cases and 576 controls for the replication study. The relation to clinical characteristics was also examined in diabetic subjects. Results. In the initial study, three SNPs of LRP6 were found to be associated with susceptibility to Type 2 DM. However, this association was not detected in the replication panel. None of SNPs in LRP5 were associated with Type 2 DM in the initial panel. Neither LRP6 nor $L R P 5$ was associated with body mass index, HOMA- $\beta$, HOMA-IR or serum lipid concentrations. Conclusions. We found no evidence for a substantial effect of LRP5 or LRP6 SNPs on susceptibility to type 2 diabetes or clinical characteristics of diabetic subjects in Japanese population.
\end{abstract}

Key words: LRP5, LRP6, Single nucleotide polymorphism, Association study, Type 2 diabetes mellitus

(Endocrine Journal 55: 699-707, 2008)

THE common form of Type 2 diabetes mellitus (DM) results from a complex interaction between genetic background and the environment. Identification of susceptibility genes for Type 2 DM has proven difficult because of the multifactorial nature of the disease. Genes responsible for monogenic disorders are potential contributors to similar conditions with a multifactorial etiology. A missense mutation (R611C) in the low density lipoprotein (LDL) receptor-related protein

Received: January 21, 2008

Accepted: February 19, 2008

Correspondence to: Kazuaki MIYAKE, Division of Diabetes, Metabolism, and Endocrinology, Department of Internal Medicine, Kobe University Graduate School of Medicine, 7-5-1 Kusunokicho, Chuo-ku, Kobe 650-0017, Japan
6 gene (LRP6) was recently shown to be causally linked to a dominant form of early-onset coronary artery disease in an Iranian family. This mutation was also linked to DM, hyperlipidemia, hypertension, and osteoporosis in the same family [1]. Mice deficient in LRP5, a closely related paralog of LRP6, manifest a marked impairment in glucose tolerance [2]. LRP5 and LRP6 are members of the LDL receptor family [3] and function as co-receptors for Wnt ligands, playing an important role in Wnt signaling [4]. The transcription factor 7-like 2 gene (TCF7L2) shows a reproducible association with Type 2 DM [5] in multiple populations, and the encoded protein also plays a role in Wnt signaling [6].

These various observations suggest that LRP5 and $L R P 6$ are potential susceptibility genes for Type 2 
DM. We therefore examined whether common variants of LRP5 and LRP6 might be associated with Type $2 \mathrm{DM}$ or dyslipidemia in Japanese individuals.

\section{Subjects and Methods}

\section{Subjects}

A total of 608 unrelated individuals with Type 2 DM and 366 unrelated nondiabetic control subjects were enrolled for the initial study. We provided another sample panel of 576 cases and 576 controls for the replication study (replication panel). In the initial panel, the mean $\pm \mathrm{SD}$ of age, body mass index (BMI), and $\mathrm{HbA}_{1 \mathrm{c}}$ were $61.3 \pm 9.9$ years, $23.8 \pm 3.4 \mathrm{~kg} / \mathrm{m}^{2}$, and $7.9 \pm 1.8 \%$, respectively, for the diabetic subjects and $75.4 \pm 8.1$ years, $21.5 \pm 3.6 \mathrm{~kg} / \mathrm{m}^{2}$, and $5.0 \pm 0.4 \%$, respectively, for the control subjects. In the replication panel, those for the cases were $60.2 \pm 11.5$ years, $23.9 \pm 4.2 \mathrm{~kg} / \mathrm{m}^{2}$, and $7.8 \pm 3.5 \%$, respectively and, for the controls, $67.3 \pm 6.5$ years, $23.0 \pm 2.9 \mathrm{~kg} / \mathrm{m}^{2}$, and $5.0 \pm 0.4 \%$, respectively. The diagnosis of Type $2 \mathrm{DM}$ was based on the criteria of the American Diabetes Association (1997). The nondiabetic subjects were selected according to the following criteria: age of $>60$ years (only for the initial panel), no past history of glucose intolerance, $\mathrm{HbA}_{1 \mathrm{c}}$ content of $\leq 5.7 \%$, and no family history of DM. The study was performed with written informed consent from all subjects and was approved by the Ethics Committee of Kobe University Graduate School of Medicine or of Gifu University School of Medicine.

\section{Clinical assessment}

The BMI of each individual was directly measured at the time of collection of blood samples. The fasting plasma glucose concentration (FPG), fasting plasma immunoreactive insulin concentration (FIRI), serum concentrations of total cholesterol and high density lipoprotein (HDL)-cholesterol, and $\mathrm{HbA}_{1 \mathrm{c}}$ level were determined by standard laboratory techniques calibrated with uniform standards. Indices of basal insulin secretion and resistance were derived by homeostasis model assessment (HOMA). The HOMA of $\beta$ cell function (HOMA- $\beta$ ) was calculated as [FIRI (pmol/l) $\times 20] /[\mathrm{FPG}(\mathrm{mmol} / \mathrm{l})-3.5] \times 6$, and that of insulin resistance (HOMA-IR) was calculated as [FPG $(\mathrm{mmol} / \mathrm{l})$ $\times$ FIRI $(\mathrm{pmol} / \mathrm{l})] / 22.5 \times 6$ [7]. The serum concentration of LDL-cholesterol was calculated as [total cholesterol $(\mathrm{mmol} / \mathrm{l})-\mathrm{HDL}$-cholesterol $(\mathrm{mmol} / \mathrm{l})$ - [triglyceride $(\mathrm{mmol} / \mathrm{l}) / 5]$ ] [8]. Among the 608 diabetic subjects of the initial panel, the 467 individuals who had not been treated with insulin were evaluated for HOMA-IR, HOMA- $\beta$, and FPG, whereas the 422 individuals who had not taken lipid-lowering drugs were evaluated for lipid parameters.

\section{DNA analysis}

We selected 13 single nucleotide polymorphisms (SNPs) of LRP6 (Fig. 1A) and nine SNPs of LRP5 (Fig. 2A) from the HapMap database (http://www. hapmap.org) according to the inclusion criteria as follows: minor allele frequencies $>0.10$ (except a nonsynonymous polymorphism, rs2302685 in LRPO) and linkage disequilibrium (LD) by $r^{2}<0.8$ in the Japanese data (JPT). Genomic DNA was extracted from blood with the use of a QIAamp DNA Blood Maxi Kit (Qiagen, Valencia, CA), and genotypes for the SNPs were determined with the TaqMan procedure (Applied Biosystems, Foster City, CA). The polymerase chain reaction was performed with ABsolute QPCR ROX Mixes (ABgene, Epsom, UK) and an ABI PRISM 7700 Sequence Detector System (Applied Biosystems); the amplification protocol included incubation at $95^{\circ} \mathrm{C}$ for $15 \mathrm{~min}$ followed by 40 cycles of $92^{\circ} \mathrm{C}$ for $15 \mathrm{~s}$ and $60^{\circ} \mathrm{C}$ for $1 \mathrm{~min}$. Sequencing of exon 9 of LRP6 was performed with the use of a Big Dye Terminator Cycle Sequencing FS Ready Reaction Kit (Applied Biosystems) and an automated DNA capillary sequencer (model 3100, Applied Biosystems).

\section{Statistical analysis}

We assessed association and Hardy-Weinberg equilibrium with the chi-square test. Linkage disequilibrium and haplotype analyses including permutation tests were performed with SNPAlyze version 5.1 pro software (Dynacom, Mobara, Japan). Haplotype estimation was performed by the expectation-maximization algorithm [9]. If we assume a minor allele frequency of 0.24 , odds ratio of 1.3 , and type I error probability $(\alpha)$ of 0.05 , the power of our initial sample (608 cases and 366 controls) computed by the PS program [10] is 0.82 . In case of combined sample (1184 cases and 942 controls), the power is 0.98 . Averaged data are pre- 
A.

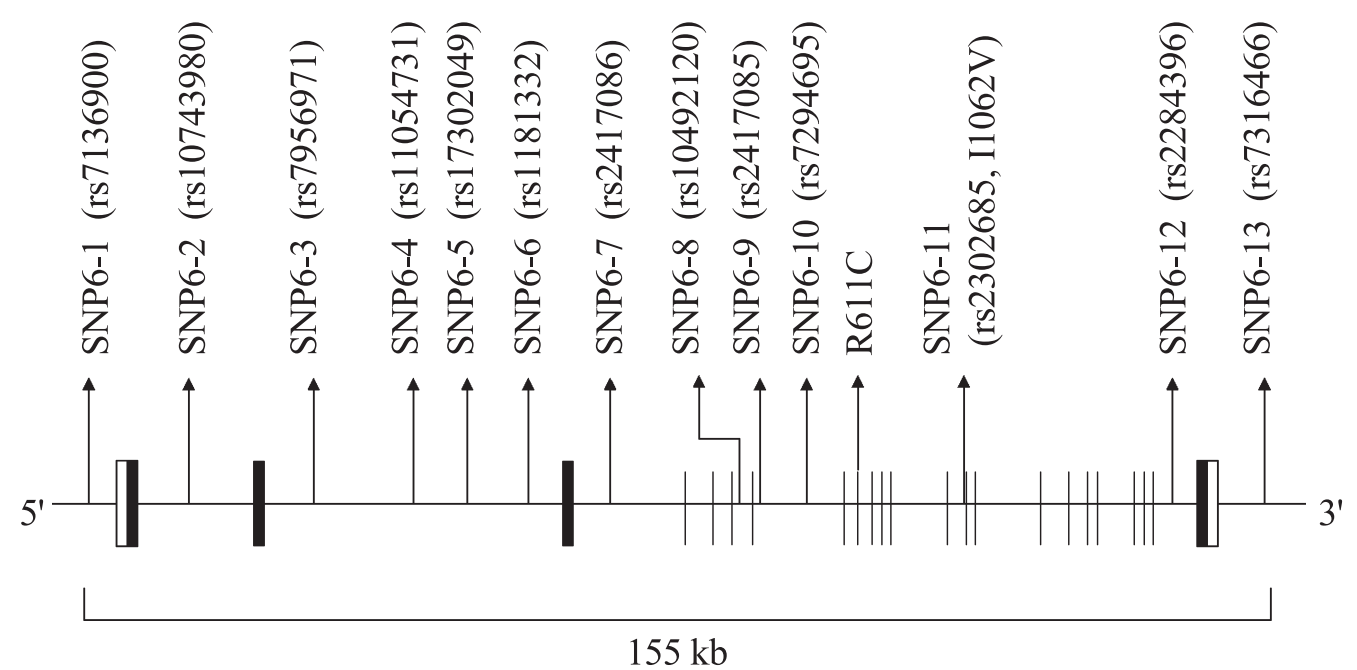

B.

\begin{tabular}{|c|c|c|c|c|c|c|c|c|c|c|c|c|c|}
\hline$D^{\prime} \backslash r^{2}$ & SNP6-1 & SNP6-2 & SNP6-3 & SNP6-4 & SNP6-5 & SNP6-6 & SNP6-7 & SNP6-8 & SNP6-9 & SNP6-10 & SNP6-1 & SNP6-12 & SNP6-13 \\
\hline SNP6-1 & & 0.20 & 0.19 & 0.08 & 0.00 & 0.39 & 0.20 & 0.00 & 0.00 & 0.13 & 0.16 & 0.13 & 0.00 \\
\hline SNP6-2 & 0.75 & & 1.00 & 0.60 & 0.09 & 0.18 & 0.94 & 0.64 & 0.64 & 0.61 & 0.11 & 0.58 & 0.32 \\
\hline SNP6-3 & 0.73 & 1.00 & & 0.60 & 0.09 & 0.19 & 0.94 & 0.66 & 0.66 & 0.60 & 0.11 & 0.58 & 0.33 \\
\hline SNP6-4 & 0.56 & 0.93 & 0.93 & & 0.12 & 0.08 & 0.60 & 0.35 & 0.35 & 0.38 & 0.02 & 0.36 & 0.18 \\
\hline SNP6-5 & -0.19 & -1.00 & -1.00 & -1.00 & & 0.02 & 0.09 & 0.06 & 0.06 & 0.06 & 0.01 & 0.06 & 0.03 \\
\hline SNP6-6 & 0.88 & 1.00 & 1.00 & 0.79 & -1.00 & & 0.18 & 0.13 & 0.13 & 0.14 & 0.52 & 0.13 & 0.10 \\
\hline SNP6-7 & 0.75 & 0.97 & 0.97 & 0.93 & -1.00 & 1.00 & & 0.64 & 0.64 & 0.56 & 0.11 & 0.53 & 0.31 \\
\hline SNP6-8 & 0.02 & 0.96 & 0.96 & 0.85 & -1.00 & 0.71 & 0.96 & & 1.00 & 0.31 & 0.16 & 0.30 & 0.52 \\
\hline SNP6-9 & 0.02 & 0.96 & 0.96 & 0.85 & -1.00 & 0.71 & 0.96 & 1.00 & & 0.31 & 0.16 & 0.30 & 0.52 \\
\hline SNP6-10 & 0.58 & 0.80 & 0.80 & 0.76 & -0.82 & 0.84 & 0.77 & 0.65 & 0.65 & & 0.12 & 0.97 & 0.62 \\
\hline SNP6-11 & 0.60 & 0.80 & 0.80 & 0.45 & -1.00 & 0.76 & 0.80 & 0.84 & 0.84 & 0.82 & & 0.17 & 0.26 \\
\hline SNP6-12 & 0.58 & 0.78 & 0.77 & 0.73 & -0.81 & 0.84 & 0.74 & 0.65 & 0.65 & 1.00 & 1.00 & & 0.66 \\
\hline SNP6-13 & -0.13 & 0.71 & 0.71 & 0.65 & -0.71 & 0.57 & 0.70 & 0.75 & 0.75 & 0.95 & 1.00 & 1.00 & \\
\hline
\end{tabular}

Fig. 1. Genomic organization of $L R P 6$ and pairwise LD analysis of SNPs. (A) Schematic representation of the LRP6 genomic region showing the locations of SNPs. Coding and noncoding sequences of exons are shown as closed and open boxes, respectively. Details of the SNPs are provided in Table 1. (B) Values of $D^{\prime}$ (bold type) and of $r^{2}$ (nonbold type) for pairwise LD analysis in 92 control subjects. Three estimated LD blocks are highlighted in gray.

sented as means $\pm \mathrm{SD}$, and differences between groups were analyzed by ANOVA; if necessary, data were log transformed. Statistical analysis was performed with StatView software version 5.0-J (SAS Institute, Cary, NC). A $P$ value of $<0.05$ was considered statistically significant.

\section{Results}

\section{LRP6}

For analysis of LD in the LRP6 genomic region, we genotyped 13 SNPs in 92 nondiabetic control subjects.
The $D^{\prime}$ and $r^{2}$ values for the 92 control subjects are shown in Fig. 1B. Two SNPs (SNP6-3, SNP6-8) were excluded from further genotyping because of their absolute LD. The remaining 11 SNPs, including a nonsynonymous polymorphism (I1062V, SNP6-11), were genotyped in all 608 Type 2 DM subjects and 366 control subjects. All SNPs with the exception of SNP6-13 were in Hardy-Weinberg equilibrium $(P>0.01)$. Association results for the 11 genotyped SNPs are shown in Table 1. We found associations between three SNPs (SNP6-1, SNP6-2, SNP6-7) and susceptibility to Type 2 DM. SNP6-7 showed the strongest association (odds ratio $=0.74,95 \%$ confidence interval $=0.59$ to 0.93 , $P=0.008)$. SNP6-2 and SNP6-7 were in strong LD 
A.

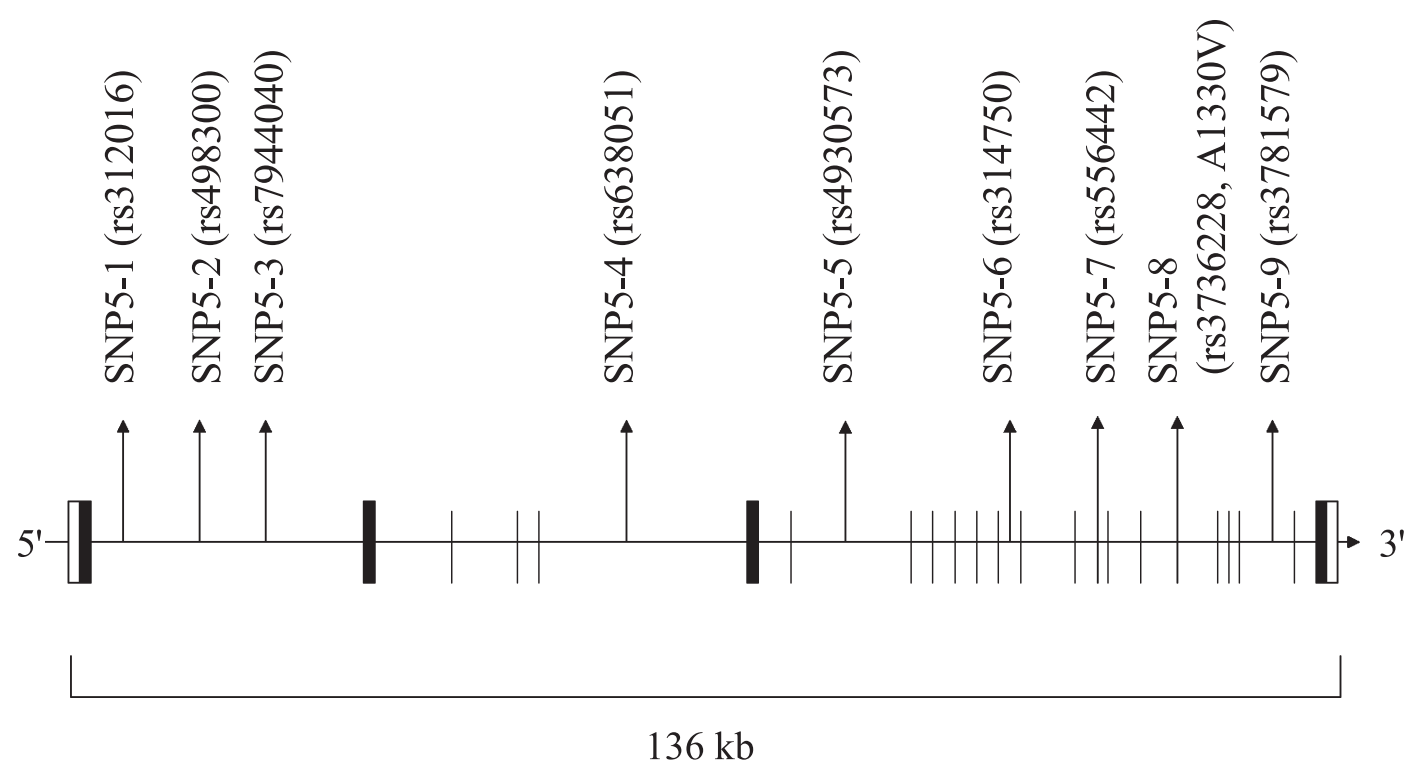

B.

$\begin{array}{lcccccccccc}D^{\prime} \backslash \mathbf{r}^{2} & \text { SNP5-1 } & \text { SNP5-2 } & \text { SNP5-3 } & \text { SNP5-4 } & \text { SNP5-5 } & \text { SNP5-6 } & \text { SNP5-7 } & \text { SNP5-8 } & \text { SNP5-9 } \\ \text { SNP5-1 } & & 0.27 & 0.12 & 0.07 & 0.00 & 0.00 & 0.00 & 0.00 & 0.00 \\ \text { SNP5-2 } & \mathbf{- 0 . 9 7} & & 0.48 & 0.08 & 0.00 & 0.03 & 0.03 & 0.01 & 0.00 \\ \text { SNP5-3 } & \mathbf{- 0 . 8 6} & \mathbf{0 . 9 1} & & 0.17 & 0.01 & 0.02 & 0.03 & 0.00 & 0.01 \\ \text { SNP5-4 } & \mathbf{- 0 . 4 4} & \mathbf{0 . 3 1} & \mathbf{0 . 6 0} & & 0.01 & 0.00 & 0.00 & 0.01 & 0.01 \\ \text { SNP5-5 } & \mathbf{0 . 0 9} & \mathbf{- 0 . 0 7} & \mathbf{0 . 1 5} & \mathbf{0 . 1 3} & & 0.20 & 0.15 & 0.21 & 0.13 \\ \text { SNP5-6 } & \mathbf{0 . 0 6} & \mathbf{0 . 2 4} & \mathbf{0 . 2 6} & \mathbf{0 . 0 7} & \mathbf{0 . 6 1} & & 0.78 & 0.57 & 0.22 \\ \text { SNP5-7 } & \mathbf{0 . 0 0} & \mathbf{0 . 2 6} & \mathbf{0 . 3 4} & \mathbf{0 . 0 9} & \mathbf{0 . 5 9} & \mathbf{0 . 9 7} & & 0.62 & 0.25 \\ \text { SNP5-8 } & \mathbf{0 . 0 5} & \mathbf{0 . 1 2} & \mathbf{0 . 1 0} & \mathbf{0 . 0 8} & \mathbf{0 . 5 4} & \mathbf{0 . 8 6} & \mathbf{0 . 9 8} & & 0.14 \\ \text { SNP5-9 } & \mathbf{- 0 . 0 9} & \mathbf{- 0 . 0 8} & \mathbf{0 . 0 8} & \mathbf{- 0 . 3 2} & \mathbf{0 . 4 6} & \mathbf{0 . 8 0} & \mathbf{0 . 9 4} & \mathbf{0 . 5 7} & \end{array}$

Fig. 2. Genomic organization of LRP5 and pairwise LD analysis of SNPs. (A) Schematic representation of the LRP5 genomic region showing the locations of SNPs. Coding and noncoding sequences of exons are shown as closed and open boxes, respectively. Details of the SNPs are provided in Table 4. (B) Values of D' (bold type) and of $r^{2}$ (nonbold type) for pairwise LD analysis in 92 control subjects. Two estimated LD blocks are highlighted in gray.

with each other $\left(r^{2}=0.94\right)$ in the 92 control subjects tested for LD. We also sequenced exon 9 of LRP6, which contains the previously identified missense mutation R611C [1]. No polymorphism was detected in the 24 diabetic and 24 control subjects subjected to such direct sequencing.

An LD block spanning SNP6-2 to SNP6-7 (Fig. 1B) encompassed a region containing exons 2 and 3 of LRP6 but did not include exon 9. Although we performed haplotype analysis with SNP6-7 and the other SNPs, we did not detect an association with Type 2 DM more significant than that of SNP6-7. A haplotype comprising SNP6-5 = A and SNP6-7 = G showed an association with Type $2 \mathrm{DM}$ similar to that of SNP6-7 alone (estimated haplotype frequencies of 0.19 and 0.24 in diabetic and control subjects, respectively; permutation $P$ value computed by 10,000 permutations $=0.006$ ).

When we consider multiple testing for the number of SNPs $(P<0.05 / 9$ SNPs; where four of 13 SNPs are not counted because of strong LD of $\left.r^{2}>0.8\right)$, the LD block including SNP6-7 is the most likely to be associated with the susceptibility to Type $2 \mathrm{DM}$. Therefore, we did not include SNP6-1 for further analysis ( $P$ value of SNP6-1 = 0.042). In order to examine a replication for the association of the SNPs or the LD block, 
Table 1. Association analysis for SNPs of LRP6 and Type 2 DM in the initial panel

\begin{tabular}{|c|c|c|c|c|c|c|c|c|}
\hline \multirow{2}{*}{$\begin{array}{c}\text { Position on } \\
\text { chromosome } 12\end{array}$} & \multirow{2}{*}{$\begin{array}{l}\text { SNP } \\
\text { name }\end{array}$} & \multirow{2}{*}{$\begin{array}{c}\text { rs } \\
\text { number }\end{array}$} & \multirow{2}{*}{$\begin{array}{l}\text { Major } \\
\text { allele }\end{array}$} & \multirow{2}{*}{$\begin{array}{l}\text { Minor } \\
\text { allele }\end{array}$} & \multicolumn{2}{|c|}{ MAF } & \multirow{2}{*}{$P$ value } & \multirow{2}{*}{$\begin{array}{l}\text { Odds ratio } \\
(95 \% \mathrm{CI})\end{array}$} \\
\hline & & & & & Case & Control & & \\
\hline 12314360 & SNP6-1 & rs7136900 & $\mathrm{G}$ & A & 0.08 & 0.10 & $0.042 *$ & $0.72(0.52-0.99)$ \\
\hline 12304062 & SNP6-2 & rs 10743980 & $\mathrm{C}$ & $\mathrm{T}$ & 0.19 & 0.23 & $0.019 *$ & $0.77(0.61-0.96)$ \\
\hline 12279248 & SNP6-3 & rs7956971 & $\mathrm{T}$ & $\mathrm{C}$ & & & & \\
\hline 12267732 & SNP6-4 & rs11054731 & G & A & 0.28 & 0.31 & 0.106 & \\
\hline 12256592 & SNP6-5 & rs 17302049 & A & G & 0.22 & 0.20 & 0.241 & \\
\hline 12253186 & SNP6-6 & rs1181332 & A & G & 0.05 & 0.05 & 0.837 & \\
\hline 12241380 & SNP6-7 & rs2417086 & A & G & 0.19 & 0.24 & $0.008 *$ & $0.74(0.59-0.93)$ \\
\hline 12224619 & SNP6-8 & rs 10492120 & $\mathrm{C}$ & $\mathrm{T}$ & & & & \\
\hline 12222642 & SNP6-9 & rs2417085 & $\mathrm{T}$ & $\mathrm{C}$ & 0.16 & 0.18 & 0.186 & \\
\hline 12214885 & SNP6-10 & rs7294695 & G & $\mathrm{C}$ & 0.19 & 0.21 & 0.293 & \\
\hline 12193165 & SNP6-11 & rs2302685 & $\mathrm{T}$ & $\mathrm{C}$ & 0.06 & 0.05 & 0.333 & \\
\hline 12166202 & SNP6-12 & rs2284396 & $\mathrm{C}$ & $\mathrm{T}$ & 0.18 & 0.22 & 0.094 & \\
\hline 12159793 & SNP6-13 & rs7316466 & $\mathrm{T}$ & $\mathrm{C}$ & 0.16 & 0.16 & 0.984 & \\
\hline
\end{tabular}

SNP position is indicated as base-pair number in NCBI build 127. MAF, minor allele frequency. $P$ values for the difference in the minor allele frequency between cases and controls were calculated by the chi-square test; the odds ratio and $95 \%$ confidence interval (CI) were also calculated for the minor allele. Asterisks indicate $P$ values of $<0.05$.

Table 2. Association analysis for rs2417086 (SNP6-7) and rs17302049 (SNP6-5)

\begin{tabular}{|c|c|c|c|c|c|c|c|}
\hline \multirow{3}{*}{ dbSNP ID } & & \multicolumn{6}{|c|}{ Initial panel } \\
\hline & & \multicolumn{2}{|r|}{$n$} & \multicolumn{2}{|c|}{ MAF } & \multirow{2}{*}{$\begin{array}{c}\text { OR } \\
(95 \% \mathrm{CI})\end{array}$} & \multirow{2}{*}{$P$} \\
\hline & & Case & Control & Case & Control & & \\
\hline \multirow[t]{3}{*}{ rs 2417086} & $\mathrm{AA}$ & 400 & 215 & 0.19 & 0.24 & 0.74 & $0.008^{*}$ \\
\hline & AG & 188 & 128 & & & $(0.59-0.93)$ & \\
\hline & GG & 20 & 23 & & & & \\
\hline \multirow[t]{3}{*}{ rs 17302049} & AA & 364 & 231 & 0.22 & 0.20 & 1.15 & 0.241 \\
\hline & AG & 214 & 113 & & & $(0.91-1.44)$ & \\
\hline & GG & 29 & 16 & & & & \\
\hline
\end{tabular}

\begin{tabular}{|c|c|c|c|c|c|c|c|}
\hline \multirow{3}{*}{ dbSNP ID } & & \multicolumn{6}{|c|}{ Replication panel } \\
\hline & & \multicolumn{2}{|r|}{$n$} & \multicolumn{2}{|c|}{ MAF } & \multirow{2}{*}{$\begin{array}{c}\text { OR } \\
(95 \% \mathrm{CI})\end{array}$} & \multirow{2}{*}{$P$} \\
\hline & & Case & Control & Case & Control & & \\
\hline \multirow[t]{3}{*}{ rs2417086 } & $\mathrm{AA}$ & 305 & 336 & 0.23 & 0.22 & 1.06 & 0.569 \\
\hline & $\mathrm{AG}$ & 167 & 175 & & & $(0.86-1.31)$ & \\
\hline & GG & 30 & 29 & & & & \\
\hline \multirow[t]{3}{*}{ rs17302049 } & AA & 322 & 329 & 0.22 & 0.23 & 0.92 & 0.451 \\
\hline & $\mathrm{AG}$ & 170 & 188 & & & $(0.75-1.13)$ & \\
\hline & GG & 28 & 33 & & & & \\
\hline
\end{tabular}

\begin{tabular}{|c|c|c|c|c|c|c|c|}
\hline \multirow{3}{*}{ dbSNP ID } & & \multicolumn{6}{|c|}{ Combined } \\
\hline & & \multicolumn{2}{|r|}{$n$} & \multicolumn{2}{|c|}{ MAF } & \multirow{2}{*}{$\begin{array}{c}\text { OR } \\
(95 \% \mathrm{CI})\end{array}$} & \multirow{2}{*}{$P$} \\
\hline & & Case & Control & Case & Control & & \\
\hline \multirow[t]{3}{*}{ rs2417086 } & AA & 705 & 551 & 0.21 & 0.22 & 0.89 & 0.130 \\
\hline & AG & 355 & 303 & & & $(0.77-1.03)$ & \\
\hline & GG & 50 & 52 & & & & \\
\hline \multirow[t]{3}{*}{ rs 17302049} & AA & 686 & 560 & 0.22 & 0.22 & 1.01 & 0.895 \\
\hline & AG & 384 & 301 & & & $(0.87-1.17)$ & \\
\hline & GG & 57 & 49 & & & & \\
\hline
\end{tabular}

SNP6-5 and SNP6-7 were genotyped in an independent sample panel (replication panel). However, none of these two SNPs or haplotypes were associated with Type $2 \mathrm{DM}$ in the replication panel (Table 2 for SNPs, data not shown for haplotypes). No association was apparent when we combined the initial panel and the replication panel (Table 2).

MAF, minor allele frequency. $P$ values for the difference in the minor allele frequency between cases and controls were calculated by the chi-square test; the odds ratio and $95 \%$ confidence interval (CI) were also calculated for the minor allele. Asterisks indicate $P$ values of $<0.05$.

Finally, we examined the relation of SNP6-7 to clinical characteristics in the diabetic subjects of the initial panel. However, no apparent association was found with BMI, HOMA-IR, HOMA- $\beta$, or serum lipid parameters (Table 3 ). 
Table 3. Clinical characteristics of Type 2 DM subjects in the initial panel according to genotype for rs2417086 (SNP6-7) of $L R P 6$.

\begin{tabular}{lllll}
\hline \multicolumn{1}{c}{ Parameter } & \multicolumn{1}{c}{ AA } & \multicolumn{1}{c}{ AG } & \multicolumn{1}{c}{ GG } & $P$ value \\
\hline Sex (male/female) & \multicolumn{1}{c}{$234 / 166$} & \multicolumn{1}{c}{$107 / 81$} & \multicolumn{1}{c}{$8 / 12$} \\
Age (years) & $61 \pm 10(n=400)$ & $61 \pm 10(n=188)$ & $59 \pm 12(n=20)$ & 0.710 \\
BMI $\left(\mathrm{kg} / \mathrm{m}^{2}\right)$ & $23.8 \pm 3.5(n=399)$ & $23.9 \pm 3.3(n=188)$ & $25.0 \pm 4.5(n=20)$ & 0.245 \\
FPG (mmol/l) & $7.7 \pm 2.5(n=307)$ & $7.5 \pm 2.0(n=139)$ & $8.2 \pm 2.8(n=19)$ & 0.285 \\
HOMA-IR* & $2.90 \pm 2.39(n=299)$ & $3.14 \pm 3.32(n=136)$ & $2.79 \pm 2.06(n=19)$ & 0.920 \\
HOMA- $\beta^{*}$ & $54.0 \pm 95.4(n=298)$ & $60.5 \pm 80.2(n=133)$ & $44.3 \pm 50.3(n=19)$ & 0.342 \\
Total cholesterol (mmol/l)* & $5.3 \pm 1.0(n=271)$ & $5.2 \pm 1.0(n=119)$ & $5.4 \pm 0.6(n=15)$ & 0.614 \\
HDL-cholesterol (mmol/l)* & $1.4 \pm 0.4(n=269)$ & $1.4 \pm 0.4(n=118)$ & $1.3 \pm 0.4(n=15)$ & 0.832 \\
LDL-cholesterol (mmol/l)* & $3.3 \pm 0.9(n=267)$ & $3.2 \pm 0.9(n=116)$ & $3.3 \pm 0.5(n=14)$ & 0.689 \\
Triglyceride (mmol/l)* & $1.4 \pm 0.8(n=271)$ & $1.7 \pm 2.6(n=119)$ & $1.8 \pm 1.3(n=15)$ & 0.302 \\
HbA $_{1 \mathrm{c}}(\%)^{*}$ & $8.0 \pm 1.9(n=400)$ & $7.7 \pm 1.7(n=187)$ & $7.7 \pm 1.7(n=20)$ & 0.312 \\
\hline
\end{tabular}

Data are means \pm SD. $P$ values were calculated by ANOVA. *These parameters were log transformed before analysis.

Table 4. Association analysis for SNPs of LRP5 and Type 2 DM in the initial panel.

\begin{tabular}{|c|c|c|c|c|c|c|c|}
\hline \multirow{2}{*}{$\begin{array}{c}\text { Position on } \\
\text { Chromosome } 11\end{array}$} & \multirow{2}{*}{ SNP name } & \multirow{2}{*}{ rs number } & \multirow{2}{*}{ Major allele } & \multirow{2}{*}{ Minor allele } & \multicolumn{2}{|c|}{ MAF } & \multirow{2}{*}{$P$ value } \\
\hline & & & & & Case & Control & \\
\hline 67838979 & SNP5-1 & rs312016 & $\mathrm{C}$ & $\mathrm{T}$ & 0.48 & 0.48 & 0.920 \\
\hline 67845407 & SNP5-2 & rs4988300 & G & $\mathrm{T}$ & 0.25 & 0.24 & 0.626 \\
\hline 67857932 & SNP5-3 & rs7944040 & $\mathrm{C}$ & $\mathrm{T}$ & 0.14 & 0.15 & 0.584 \\
\hline 67897990 & SNP5-4 & rs638051 & A & G & 0.26 & 0.28 & 0.442 \\
\hline 67920032 & SNP5-5 & rs4930573 & $\mathrm{C}$ & G & 0.22 & 0.23 & 0.591 \\
\hline 67938604 & SNP5-6 & rs314750 & A & G & 0.33 & 0.36 & 0.244 \\
\hline 67949266 & SNP5-7 & rs556442 & A & G & 0.37 & 0.40 & 0.171 \\
\hline 67957871 & SNP5-8 & rs3736228 & $\mathrm{C}$ & $\mathrm{T}$ & 0.29 & 0.30 & 0.587 \\
\hline 67966294 & SNP5-9 & rs3781579 & $\mathrm{T}$ & $\mathrm{C}$ & 0.16 & 0.16 & 0.820 \\
\hline
\end{tabular}

SNP position is indicated as base-pair number in NCBI build 127. MAF, minor allele frequency. $P$ values for the difference in the minor allele frequency between cases and controls were calculated by the chi-square test.

\section{LRP5}

Nine SNPs including a non-synonymous SNP (A1330V, SNP5-8) were genotyped in 92 control subjects. The $D^{\prime}$ and $r^{2}$ values for these subjects are shown in Fig. 2B. Then all polymorphisms were genotyped in the initial panel of 608 Type 2 DM subjects and 366 control subjects. They were in HardyWeinberg equilibrium $(\mathrm{P}>0.01)$.

The results of association tests for susceptibility to Type $2 \mathrm{DM}$ are shown in Table 4. No association between SNPs of LRP5 and Type 2 DM was apparent in this panel. Next, we assessed the relations between all SNPs and clinical characteristics, BMI, HOMA-IR, HOMA- $\beta$, or serum lipid parameters in the diabetic subjects. However, no association was detected (data not shown).

\section{Discussion}

We found no evidence for a substantial effect of LRP5 or LRP6 SNPs on susceptibility to type $2 \mathrm{DM}$ in Japanese population. The association of rs 2417086 (SNP6-7) or haplotype analysis in LRP6 observed in the initial panel could be false positive due to the small sample number. A previous study showed that a mutation in LRP6 was genetically linked with a familial disorder characterized by early-onset coronary artery disease as well as hyperlipidemia, hypertension, DM, and osteoporosis [1]. Genes that cause rare monogenic disorders might also confer susceptibility to similar conditions with a multifactorial etiology, although we failed to detect such a case. For example, genes responsible for maturity-onset diabetes of the young, an autosomal dominant monogenic form of DM, have also been associated with Type 2 DM [11-14]. 
LRP5 and LRP6 are co-receptors for Wnt ligands [4, 15]. Wnt signaling is necessary for embryogenesis but also plays important roles in postnatal development and tissue homeostasis. Mouse embryos homozygous for an insertion mutation in Lrp6 exhibit a variety of severe developmental abnormalities, including midbrain defects, truncation of the skeleton, and limb anomalies [4]. Lrp6 mutations cause early-onset osteoporosis in mice [16]. $\mathrm{Lrp}^{-/-}$mice exhibit low bone density and frequent bone fractures. In human, mutations in LRP5 cause the autosomal recessive disorder osteoporosis-pseudoglioma syndrome (OPPG) [17, 18]. Recently, some reports showed that polymorphisms of LRP5 were associated with bone mineral density [1921]. Meanwhile, LRP5 plays an important role in glucose and lipid metabolism, with Lrp5 knockout mice showing a marked impairment in glucose tolerance as a result of a reduced level of glucose-induced insulin secretion. Maintenance of these knockout mice on a high-fat diet also increases the plasma concentration of cholesterol to levels greater than those apparent in similarly fed normal mice [2]. We assessed whether polymorphisms of LRP5 or LRP6 were associated with HOMA-IR, HOMA- $\beta$, or lipid parameters in patients with Type 2 DM. However, no such association was detected. We did not evaluate whether the polymorphisms were associated with osteoporosis or cardiovascular disease because information was not available for these disorders. Recently, Guo et al. showed that a haplotype including rs4988300 (SNP5-2) in LRP5 was associated with BMI in Caucasian diabetic subjects [22]. Although we investigated the association between BMI and this polymorphism or haplotypes comprising SNP5-1 to SNP5-3, there was no association (data not shown).

To date, TCF7L2 (also known as TCF4) has been the gene most reproducibly associated with Type 2 DM [5]. TCF7L2 is a transcription factor that partners with $\beta$-catenin in the canonical Wnt signaling pathway [6]. Wnt signaling and $\beta$-catenin are necessary for the proliferation of pancreas including $\beta$ cells in mice [23-25]. Elucidation of the mechanisms by which this signaling pathway contributes to regulation of glucose metabolism may provide insight into the pathogenesis of Type 2 DM.

In conclusion, our results failed to reveal an association between Type $2 \mathrm{DM}$ and SNPs or haplotypes of LRP5 and LRP6. Furthermore, we found no association between these genes and any clinical characteristics such as serum LDL-cholesterol in the subjects with Type 2 DM. Similar studies are needed to clarify whether variants of LRP5 and LRP6 may be associated with coronary artery disease, hyperlipidemia, hypertension as well as Type $2 \mathrm{DM}$.

\section{Acknowledgments}

We thank T. Fukui, T. Katsumura, and K. Komuro for technical assistance. This work was supported by the 21st Century COE Program "Center of Excellence for Signal Transduction Disease: Diabetes Mellitus as Model" and by a Grant-in-Aid for Scientific Research on Priority Areas "Applied Genomics" from the Ministry of Education, Culture, Sports, Science, and Technology of Japan. This work was also supported in part by the New Energy and Industrial Technology Development Organization to Y. Horikawa.

\section{References}

1. Mani A, Radhakrishnan J, Wang H, Mani A, Mani MA, Nelson-Williams C, Carew KS, Mane S, Najmabadi H, Wu D, Lifton RP (2007) LRP6 mutation in a family with early coronary disease and metabolic risk factors. Science 315: 1278-1282.

2. Fujino T, Asaba H, Kang MJ, Ikeda Y, Sone H, Takada S, Kim DH, Ioka RX, Ono M, Tomoyori H, Okubo M, Murase T, Kamataki A, Yamamoto J, Magoori K, Takahashi S, Miyamoto Y, Oishi H, Nose M, Okazaki M, Usui S, Imaizumi K, Yanagisawa M, Sakai J, Yamamoto TT (2003) Low-density lipoprotein receptor-related protein 5 (LRP5) is essential for normal cholesterol metabolism and glucose-induced insulin secretion. Proc Natl Acad Sci USA 100: 229-234.

3. Caskey CT, Todd JA, Hess JF (1998) Isolation and characterization of LRP6, a novel member of the low density lipoprotein receptor gene family. Biochem Biophys Res Commun 248: 879-888.

4. Pinson KI, Brennan J, Monkley S, Avery BJ, Skarnes WC (2000) An LDL-receptor-related protein mediates Wnt signalling in mice. Nature 407: 535-538.

5. Grant SF, Thorleifsson G, Reynisdottir I, Benediktsson R, Manolescu A, Sainz J, Helgason A, Stefansson H, Emilsson V, Helgadottir A, Styrkarsdottir U, 
Magnusson KP, Walters GB, Palsdottir E, Jonsdottir T, Gudmundsdottir T, Gylfason A, Saemundsdottir J, Wilensky RL, Reilly MP, Rader DJ, Bagger Y, Christiansen C, Gudnason V, Sigurdsson G, Thorsteinsdottir U, Gulcher JR, Kong A, and Stefansson K (2006) Variant of transcription factor 7-like 2 (TCF7L2) gene confers risk of type 2 diabetes. Nat Genet 38: 320-323.

6. Yi F, Brubaker PL, Jin T (2005) TCF-4 mediates cell type-specific regulation of proglucagon gene expression by $\beta$-catenin and glycogen synthase kinase- $3 \beta . J$ Biol Chem 280: 1457-1464.

7. Matthews DR, Hosker JP, Rudenski AS, Naylor BA, Treacher DF, Turner RC (1985) Homeostasis model assessment: insulin resistance and beta-cell function from fasting plasma glucose and insulin concentrations in man. Diabetologia 28: 412-419.

8. Friedewald WT, Levy RI, Fredrickson DS (1972) Estimation of the concentration of low-density lipoprotein cholesterol in plasma, without use of the preparative ultracentrifuge. Clin Chem 18: 499-502.

9. Excoffier L, Slatkin M (1995) Maximum-likelihood estimation of molecular haplotype frequencies in a diploid population. Mol Biol Evol 12: 921-927.

10. Dupont WD, Plummer Jr WD. (1998) Power and sample size calculations for studies involving linear regression. Control Clin Trials 19: 589-601.

11. Bonnycastle LL, Willer CJ, Conneely KN, Jackson AU, Burrill CP, Watanabe RM, Chines PS, Narisu N, Scott LJ, Enloe ST, Swift AJ, Duren WL, Stringham HM, Erdos MR, Riebow NR, Buchanan TA, Valle TT, Tuomilehto J, Bergman RN, Mohlke KL, Boehnke M, Collins FS (2006) Common variants in maturity-onset diabetes of the young genes contribute to risk of type 2 diabetes in Finns. Diabetes 55: 2534-2540.

12. Gudmundsson J, Sulem P, Steinthorsdottir V, Bergthorsson JT, Thorleifsson G, Manolescu A, Rafnar T, Gudbjartsson D, Agnarsson BA, Baker A, Sigurdsson A, Benediktsdottir KR, Jakobsdottir M, Blondal T, Stacey SN, Helgason A, Gunnarsdottir S, Olafsdottir A, Kristinsson KT, Birgisdottir B, Ghosh S, Thorlacius S, Magnusdottir D, Stefansdottir G, Kristjansson K, Bagger Y, Wilensky RL, Reilly MP, Morris AD, Kimber CH, Adeyemo A, Chen Y, Zhou J, So WY, Tong PC, Ng MC, Hansen T, Andersen G, Borch-Johnsen K, Jorgensen T, Tres A, Fuertes F, Ruiz-Echarri M, Asin L, Saez B, van Boven E, Klaver S, Swinkels DW, Aben KK, Graif T, Cashy J, Suarez BK, van Vierssen Trip O, Frigge ML, Ober C, Hofker MH, Wijmenga C, Christiansen C, Rader DJ, Palmer CN, Rotimi C, Chan JC, Pedersen O, Sigurdsson G, Benediktsson R, Jonsson E, Einarsson GV, Mayordomo JI, Catalona WJ, Kiemeney LA, Barkardottir RB, Gulcher JR, Thorsteinsdottir U, Kong A, Stefansson K (2007) Two variants on chromosome 17 confer prostate cancer risk, and the one in TCF2 protects against type 2 diabetes. Nat Genet 39: 977-983.

13. Love-Gregory LD, Wasson J, Ma J, Jin CH, Glaser B, Suarez BK, Permutt MA (2004) A common polymorphism in the upstream promoter region of the hepatocyte nuclear factor- $4 \alpha$ gene on chromosome $20 \mathrm{q}$ is associated with type 2 diabetes and appears to contribute to the evidence for linkage in an Ashkenazi Jewish population. Diabetes 53: 1134-1140.

14. Silander K, Mohlke KL, Scott LJ, Peck EC, Hollstein P, Skol AD, Jackson AU, Deloukas P, Hunt S, Stavrides G, Chines PS, Erdos MR, Narisu N, Conneely KN, Li C, Fingerlin TE, Dhanjal SK, Valle TT, Bergman RN, Tuomilehto J, Watanabe RM, Boehnke M, Collins FS (2004) Genetic variation near the hepatocyte nuclear factor- $4 \alpha$ gene predicts susceptibility to type 2 diabetes. Diabetes 53: 1141-1149.

15. He X, Semenov M, Tamai K, Zeng X (2004) LDL receptor-related proteins 5 and 6 in Wnt/ $\beta$-catenin signaling: Arrows point the way. Development 131: 1663-1677.

16. Kokubu C, Heinzmann U, Kokubu T, Sakai N, Kubota T, Kawai M, Wahl MB , Galceran J, Grosschedl R, Ozono K, Imai K (2004) Skeletal defects in ringelschwanz mutant mice reveal that Lrp6 is required for proper somitogenesis and osteogenesis. Development 131: 5469-5480.

17. Gong Y, Slee RB, Fukai N, Rawadi G, Roman-Roman S, Reginato AM, Wang H, Cundy T, Glorieux FH, Lev D, Zacharin M, Oexle K, Marcelino J, Suwairi W, Heeger S, Sabatakos G, Apte S, Adkins WN, Allgrove J, Arslan-Kirchner M, Batch JA, Beighton P, Black GC, Boles RG, Boon LM, Borrone C, Brunner HG, Carle GF, Dallapiccola B, De Paepe A, Floege B, Halfhide ML, Hall B, Hennekam RC, Hirose T, Jans A, Jüppner H, Kim CA, Keppler-Noreuil K, Kohlschuetter A, LaCombe D, Lambert M, Lemyre E, Letteboer T, Peltonen L, Ramesar RS, Romanengo M, Somer H, Steichen-Gersdorf E, Steinmann B, Sullivan B, SupertiFurga A, Swoboda W, van den Boogaard MJ, Van Hul W, Vikkula M, Votruba M, Zabel B, Garcia T, Baron R, Olsen BR, Warman ML, Osteoporosis-Pseudoglioma Syndrome Collaborative Group (2001) LDL receptorrelated protein 5 (LRP5) affects bone accrual and eye development. Cell 107: 513-523.

18. Kato M, Patel MS, Levasseur R, Lobov I, Chang BH, Glass DA $2^{\text {nd }}$, Hartmann C, Li L, Hwang TH, Brayton CF, Lang RA, Karsenty G, Chan L (2002) Cbfa1-independent decrease in osteoblast proliferation, osteopenia, and persistent embryonic eye vascularization in mice deficient in Lrp5, a Wnt coreceptor. J Cell Biol 157: 303-314.

19. Ezura Y, Nakajima T, Urano T, Sudo Y, Kajita M, Yoshida H, Suzuki T, Hosoi T, Inoue S, Shiraki M, Emi M (2007) Association of a single-nucleotide varia- 
tion $(\mathrm{A} 1330 \mathrm{~V})$ in the low-density lipoprotein receptorrelated protein 5 gene (LRP5) with bone mineral density in adult Japanese women. Bone 40: 997-1005.

20. Ferrari SL, Deutsch S, Baudoin C, Cohen-Solal M, Ostertag A, Antonarakis SE, Rizzoli R, de Vernejoul MC (2005) LRP5 gene polymorphisms and idiopathic osteoporosis in men. LRP5 gene polymorphisms and idiopathic osteoporosis in men. Bone 37: 770-775.

21. Ferrari SL, Deutsch S, Choudhury U, Chevalley T, Bonjour JP, Dermitzakis ET, Rizzoli R, Antonarakis SE (2004) Polymorphisms in the low-density lipoprotein receptor-related protein 5 (LRP5) gene are associated with variation in vertebral bone mass, vertebral bone size, and stature in whites. Am J Hum Genet 74: 866-875.

22. Guo YF, Xiong DH, Shen H, Zhao LJ, Xiao P, Guo Y, Wang W, Yang TL, Recker RR, Deng HW (2006)
Polymorphisms of the low-density lipoprotein receptor-related protein 5 (LRP5) gene are associated with obesity phenotypes in a large family-based association study. J Med Genet 43: 798-803.

23. Dessimoz J, Bonnard C, Huelsken J, Grapin-Botton A (2005) Pancreas-specific deletion of $\beta$-catenin reveals Wnt-dependent and Wnt-independent functions during development. Curr Biol 15: 1677-1683.

24. Heller RS, Dichmann DS, Jensen J, Miller C, Wong G, Madsen OD, Serup P (2002) Expression patterns of Wnts, Frizzleds, sFRPs, and misexpression in transgenic mice suggesting a role for Wnts in pancreas and foregut pattern formation. Dev Dyn 225: 260-270.

25. Rulifson IC, Karnik SK, Heiser PW, ten Berge D, Chen $\mathrm{H}, \mathrm{Gu}$ X (2007) Wnt signaling regulates pancreatic beta cell proliferation. Proc Natl Acad Sci USA 104: 6247-6252. 